\title{
Vitamin C dietary supplementation influence tadpoles of bullfrog Lithobates catesbeianus reared in low water temperature
}

\author{
A suplementação da dieta com vitamina C influencia os girinos de \\ rã-touro Lithobates catesbeianus criados em baixa temperatura da água
}

\author{
Rodrigo Diana Navarro $^{1}$ (D); Tamyres Pereira Araújo Martins ${ }^{1}$; Marcelo Maia Pereira ${ }^{2}$ \\ ${ }^{1}$ Universidade de Brasília, Laboratório de Aquicultura, Campus Darcy Ribeiro, Brasília - DF, Brazil \\ ${ }^{2}$ Fundação Instituto de Pesca do Estado do Rio de Janeiro, Rio de Janeiro - RJ, Brazil
}

\begin{abstract}
Vitamin C supplementation is important for the growth and development of bullfrog tadpoles under optimum water temperature conditions. Therefore, an experiment was carried out to evaluate the effects of vitamin $\mathrm{C}$ supplementation on the diet of bullfrog tadpoles at a low temperature. A total of 480 tadpoles with a mean weight of $0.078 \mathrm{~g}$ were distributed in 12 aquariums each containing $40 \mathrm{~L}$ of water in a closed water recirculation system. The experimental design was entirely randomized with four treatments $\left(0,150,300\right.$, and $600 \mathrm{mg} \mathrm{kg}^{-1}$ of L-ascorbic acid monophosphate) and three replicates. The productive performance was measured by the weight gain, feed conversion, diet consumption, protein efficiency, carcass yield, hepatosomatic index, viscerosomatic index, visceral fat index, dry matter, and ethereal carcass extract. The water temperature during the experimental period was $21.74 \pm 0.43^{\circ} \mathrm{C}$. Vitamin $\mathrm{C}$ supplementation did not influence carcass yield and viscerosomatic index. However, there was a quadratic effect of vitamin $\mathrm{C}$ supplementation on the weight gain, apparent feed conversion, protein efficiency, visceral fat index, hepatosomatic index, and ethereal carcass extract. Based on these results, bullfrog tadpoles should be supplemented with $600 \mathrm{mg}$ vitamin $\mathrm{C} \mathrm{kg}^{-1} \mathrm{of}$ the diet when subjected to water temperatures of around $22^{\circ} \mathrm{C}$.
\end{abstract}

Keywords: Ascorbic acid. Zootechnical performance. Lithobates catesbeianus. Nutrition.

\section{RESUMO}

A suplementação de vitamina C é importante para o crescimento e desenvolvimento de girinos de rã-touro sob condições ótimas de temperatura da água. Desta forma, foi realizado um experimento para avaliar o efeito da suplementação de vitamina $\mathrm{C}$ sobre a dieta de girinos de rã-touro em baixa temperatura. $\mathrm{O}$ experimento foi realizado com 480 girinos com peso médio de $0,078 \mathrm{~g}$, distribuídos em 12 aquários com $40 \mathrm{~L}$ de água em sistema fechado de recirculação de água. O delineamento experimental foi inteiramente casualizado, com quatro tratamentos $(0,150,300$ e $600 \mathrm{mg} \mathrm{kg}-1 \mathrm{de}$ monofosfato de ácido L-ascórbico) e três repetições. O desempenho produtivo foi avaliado por meio de ganho de peso, conversão alimentar, consumo de ração, eficiência proteica, rendimento de carcaça, índice hepatossomático, índice viscerossomático, índice de gordura visceral, matéria seca e extrato etéreo de carcaça. A temperatura da água durante o período experimental foi de $21,74 \pm 0,43^{\circ} \mathrm{C}$. A suplementação com vitamina $\mathrm{C}$ não influenciou o rendimento de carcaça e o índice viscerossomático. No entanto, houve efeito quadrático da suplementação com vitamina C sobre o ganho de peso, a conversão alimentar aparente, a eficiência protéica, o índice de gordura visceral, o índice hepatossomático e o extrato etéreo de carcaça. Com base nos resultados do presente estudo, os girinos de rã-touro devem ser suplementados com $600 \mathrm{mg}$ vitamina $\mathrm{C} \mathrm{kg}^{-1}$ da dieta quando submetidos em temperaturas médias de $22^{\circ} \mathrm{C}$.

Palavras-chave: Ácido ascórbico. Desempenho zootécnico. Lithobates catesbeianus. Nutrição. 
Correspondence to:

Rodrigo Diana Navarro

Universidade de Brasília, Laboratório de Aquicultura

Campus Darcy Ribeiro

Brasília - DF, Brazil

e-mail: navarrounb@gmail.com

Received: April 2, 2020

Approved: February 10, 2021

How to cite: Navarro RD, Martins TPA, Pereira MM. Vitamin C dietary supplementation influence tadpoles of bullfrog Lithobates catesbeianus reared in low water temperature. Braz J Vet Res Anim Sci. 2021;58: e168438. https://doi.org/10.11606/issn.1678-4456.bjvras.2021.168438

\section{Introduction}

The high productivity and nutritional quality of the bullfrog carcass, Lithobates catesbeianus, are contributing factors for the development of this productive sector. However, the sector still presents a scarcity of technical management information, mainly during the tadpole development phase, because during this phase the production of quality and quantity froglets is determined for the fattening phase (Castro \& Pinto, 2000; Hayashi et al., 2004; Pahor-Filho et al., 2019).

As an ectothermal animal, tadpoles kept under a high interval of thermal discomfort do not develop (Knoop et al., 2015; Godome et al., 2018), as this parameter directly influences food consumption caused by thermal stress, compromising the healthy development of these animals (Braga \& Lima, 2001). This can be confirmed in the study by Hoffmann et al. (1988), which observed that the tadpoles presented higher biomass and less time to complete metamorphosis when kept at elevated temperatures, with the ideal temperature around $25^{\circ} \mathrm{C}$.

Several studies have demonstrated the benefits of vitamin supplementations to the diet of aquatic organisms, with emphasis on ascorbic acid, aiming at the improvement of zootechnical performance indices (Zhou et al., 2012; Gao et al., 2014; Castillo \& Parra, 2019).

In fish, the absence of or inactivity of the enzyme L-gulonolactone oxidase, which catalyzes the ultimate reaction of ascorbic acid synthesis from glucose, induces skeletal and opercular deformities mainly in the early stages (Neu et al., 2010; Zhou et al. al., 2012), exophthalmia, anemia, lethargy, increased mortality rate, and increased negative stress effects (Rotta, 2003).

Amphibians, unlike fish, have the ascorbic acid synthesis enzyme. However, the amount of vitamin C synthesized is insufficient to maintain the physiological functions and, therefore, dietary supplementation is necessary when in intensive production systems, since natural food is restricted (Drouin et al., 2011).

According to Lim \& Lovell (1978), minute amounts of vitamin $\mathrm{C}$ meet the physiological needs of the species, although high concentrations are required for higher responses to disease resistance and tolerance to environmental stress.

Ascorbic acid deficiency in tadpoles has been observed by an increased mortality rate and deformations in the tail structure (Leibovitz et al., 1982). According to the study by De Stéfani et al. (2001), the tadpole survival rate was significantly higher in the group supplemented with $500 \mathrm{mg}$ vitamin $\mathrm{C} \mathrm{kg}^{-1}$ (62.83\%), compared to the control group (40.48\%).

Considering these factors, this study objective was to evaluate the effects of supplementation of dietary vitamin C levels on the growth and performance of bullfrog tadpoles, Lithobates catesbeianus, submitted to low temperatures.

\section{Material and methods}

The experiment was performed at the Aquaculture Laboratory of the University of Brasília for 60 days, and 480 bullfrog tadpoles (Lithobates catesbeianus) were used in stage 25 of Gosner's simplified table (Gosner, 1960), bred from the same spawning, with an initial average weight of $0.078 \mathrm{~g}$ (precision scale of 0.0001 ). The tadpoles were distributed in 12 aquariums with 40L of water, in the density of 1 tadpole/L of water, in a closed water recirculation system. Each aquarium was considered an experimental unit, totaling 12 experimental units. The experiment was carried out according to Martins et al. (2016).

Commercial diets for Nile tilapia (Oreochomis niloticus) with 32\% CP were used and 3 levels of vitamin C (L-ascorbic acid monophosphate) supplementation were tested, $\mathrm{T} 1$ - control ration (CR), T2 - $\mathrm{RC}+150 \mathrm{mg}$ vitamin $\mathrm{C} \mathrm{kg}^{-1}$, $\mathrm{T} 3-\mathrm{CR}+300 \mathrm{mg}$ vitamin $\mathrm{C} \mathrm{kg}^{-1}$, and $\mathrm{T} 4-\mathrm{CR}+600 \mathrm{mg}$ vitamin $\mathrm{C} \mathrm{kg}^{-1}$, with three replicates, following a completely randomized design. The feed was ground and then incorporated with vitamin $\mathrm{C}$ according to each treatment.

The total daily diet was divided into four meals (8:00 am, 11:00 am, 2:00 pm, and 5:00 pm). The food was ground and stored under refrigeration at $4{ }^{\circ} \mathrm{C}$. Biometrics of a portion of each repetition was performed every four days, to adjust the food supplied to $5 \%$ of live weight. Vitamin C was incorporated into the diet with the premix.

The water temperature was monitored daily (8 am and $5 \mathrm{pm}$ ) throughout the experimentation period. At the end of the experimentation period, the animals from each experimental unit were counted, weighed, and measured individually. The 
total length (head to tail end) and partial length (head to tail insertion) were recorded using a pachymeter. The weight of each tadpole was recorded in an analytical balance.

The digestive system was dissected and separated into a digestive tube, liver, and visceral fat, which were weighed on an analytical balance (Figure 1 and 2) for later calculation of the viscerosomal index (VI), hepatosomatic index (HI), and visceral fat index (VFI), where: $\mathrm{HI}=(\mathrm{WL} \div \mathrm{PF}) \times 100$; IVS $=($ Wvis. $\div \mathrm{PF}) \times 100 ; \mathrm{VFI}=(\mathrm{WG} \div \mathrm{PF}) \times 100$ where; $\mathrm{WL}=$ liver weight; $\mathrm{WF}=$ final weight; Wvisc. $=$ weight of the viscera; $\mathrm{WVF}=$ weight of visceral fat.

To determine the zootechnical performance, weight gain (WG), apparent feed consumption (CRA), apparent feed conversion (CAA), and carcass yield (CY) were analyzed: WG $(\mathrm{g})=\mathrm{FW}-\mathrm{PI} \mathrm{CAA}=\mathrm{CRA} \div \mathrm{WG} \mathrm{CY}$ $(\%)=[(\mathrm{CCW} \times 100) \div \mathrm{PF})]$ where, $\mathrm{PI}=$ initial weight; $\mathrm{CCW}=$ clean carcass weight. To evaluate the carcass quality, dry matter (CDM) and ether extract (CEE) of the tadpole's carcass was analyzed. To assess the efficiency of protein utilization by tadpoles, the protein rate and efficiency (PER) were calculated: $\mathrm{PER}=(\mathrm{WG} \div$ protein ingested $) \times 100$.

The gain in weight (GP), apparent feed intake (AFI), apparent feed conversion (AFC), and carcass yield (CY) were analyzed for the determination of the zootechnical performance. The protein efficiency rate (PER), dry matter (CDM), and ethereal extract (CEE) of tadpoles carcass were also analyzed.

The data were submitted to analysis of variance, at $5 \%$ of significance, and later adjusted to a polynomial regression equation by the SAS Institute (2008) program.

\section{Results}

The mean temperature observed over the experimental period was $21.74 \pm 0.43^{\circ} \mathrm{C}$. We observed that the increase in vitamin $\mathrm{C}$ supplementation levels increased the total and partial length (Table 1), respectively. The values of final weight and weight gain varied in a quadratic form

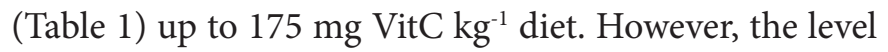
that presented maximum value for apparent feed conversion

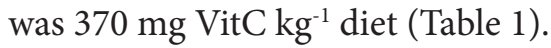

The scatter plot of the averages of treatments and the polynomial regression equation for protein efficiency ratio is shown in Table 1. Quadratic effect $(\mathrm{p}<0.05)$ of the vitamin $\mathrm{C}$ supplementation was observed for the protein efficiency rate, with an optimal inclusion level observed of $272.5 \mathrm{mg} \mathrm{kg}^{-1}$ of vitamin $\mathrm{C}$ to the diet.

The levels of vitamin $\mathrm{C}$ did not influence ( $\mathrm{p}>0.05)$ the viscerosomatic index and carcass yield. There was a quadratic effect of vitamin $\mathrm{C}$ supplementation $(\mathrm{p}<0.05)$ on the liver weight and viscera weight.

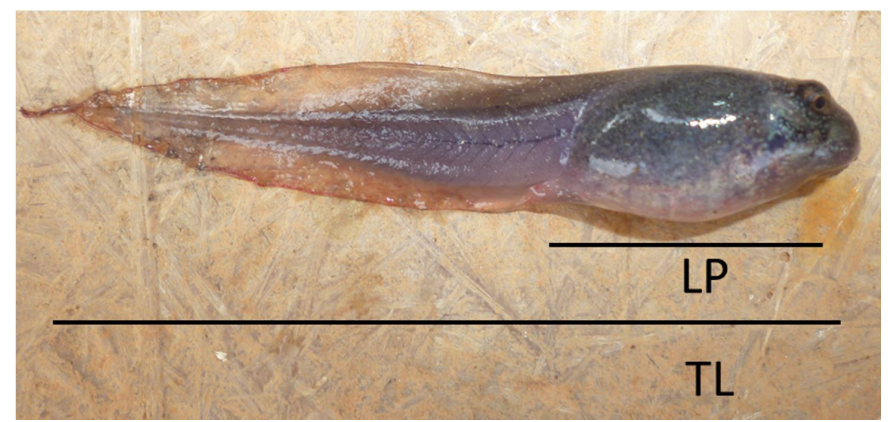

Figure 1 -Tadpole of L. catesbeianus showing the total (TL) and partial (LP) length.

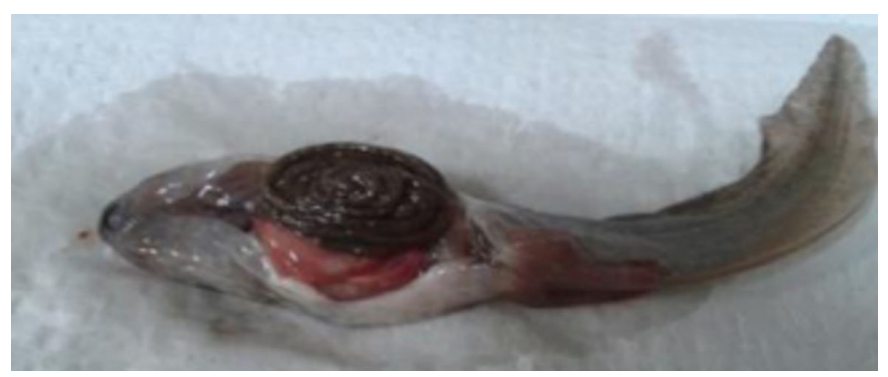

Figure 2 - Visceral exposure of L. catesbeianus tadpole for later evisceration.

Table 1 - Final weight (FW), total length (TL), partial length (PL), weight gain (WG), apparent feed intake (AFI), and apparent feed conversion (AFC) Protein efficiency rate (PER) of frog tadpoles -trout fed different levels of vitamin C supplementation to the diet.

\begin{tabular}{|c|c|c|c|c|c|}
\hline \multicolumn{5}{|c|}{ Vitamin C mg kg ${ }^{-1}$} & \multirow{2}{*}{ C.V.(\%) ${ }^{1}$} \\
\hline & 0 & 150 & 300 & 600 & \\
\hline $\mathrm{FW}(\mathrm{g})^{2}$ & $0.76 \pm 0.07$ & $0.70 \pm 0.03$ & $0.67 \pm 0.08$ & $0.88 \pm 0.08$ & $0.76^{*}$ \\
\hline $\mathrm{TL}(\mathrm{cm})^{3}$ & $4.06 \pm 0.12$ & $3.86 \pm 0.06$ & $3.77 \pm 0.12$ & $4.18 \pm 0.14$ & $4.70^{*}$ \\
\hline $\mathrm{PL}(\mathrm{cm})^{4}$ & $1.37 \pm 0.09$ & $1.34 \pm 0.06$ & $1.31 \pm 0.11$ & $1.44 \pm 0.06$ & $4.08^{*}$ \\
\hline $\mathrm{AFI}(\mathrm{g})$ & $2.84 \pm 0.00$ & $2.89 \pm 0.00$ & $2.83 \pm 0.00$ & $3.43 \pm 0.00$ & 9.64 \\
\hline WG $(g)^{5}$ & $0.68 \pm 0.07$ & $0.63 \pm 0.03$ & $0.60 \pm 0.08$ & $0.80 \pm 0.08$ & $13.61^{*}$ \\
\hline $\operatorname{AFC}(g / g)^{6}$ & $4.31 \pm 0.50$ & $4.78 \pm 0.32$ & $5.59 \pm 0.26$ & $4.42 \pm 0.42$ & $12.08^{*}$ \\
\hline $\operatorname{PER}(\%)^{7}$ & $81.67 \pm 5.23$ & $78.02 \pm 4.41$ & $62.78 \pm 6.17$ & $84.10 \pm 3.72$ & $12.49^{*}$ \\
\hline
\end{tabular}

Values in mean \pm standard error; ${ }^{*} \mathrm{p}<0.05{ }^{1}$ Coefficient of variation; ${ }^{2}$ Quadratic effect FW-Y $=2 \mathrm{E}-06 \mathrm{x} 2-0.0007 \mathrm{x}+0.7669, \mathrm{R}^{2}=0.9848 ;{ }^{3}$ Quadratic effect TL- $Y=4 \mathrm{E}-06 \mathrm{x} 2-0.0021 \mathrm{x}+4.0695, \mathrm{R}^{2}=0.9964 ;{ }^{4}$ Quadratic effect PL- $\mathrm{Y}=9 \mathrm{E}-07 \mathrm{x} 2-0.0005 \mathrm{x}+1.3747, \mathrm{R}^{2}=0.9371 ;{ }^{5} \mathrm{Quadratic}$ effect WG $-Y=2 E-06 x 2-0.0007 x+0.6889, R^{2}=0.9848 ;{ }^{6}$ Quadratic effect AFC- $Y=-1 E-05 x 2+0.0074 x+4.2083, R^{2}=0.87 ;{ }^{7}$ Quadratic effect PER $-Y=0.0002 \times 2-0.109 x+8.4028, R^{2}=0.7523$. 
Table 2 - Liver weight (LW), Fat weight (FW), Weight of viscera (Wvisc), Hepatosomatic index (HSI), Visceral fat index (VFI), Viscerosomal index (VSI), Carcass yield (CY), and Dry matter (CDM) carcass composition and ethereal extract (CEE) (Mean values \pm standard error) of bullfrog tadpoles fed different levels of dietary vitamin $\mathrm{C}$ supplementation.

\begin{tabular}{|c|c|c|c|c|c|}
\hline \multicolumn{5}{|c|}{ Vitamin C mg kg ${ }^{-1}$} & \multirow{2}{*}{ C.V. $(\%)^{1}$} \\
\hline & 0 & 150 & 300 & 600 & \\
\hline $\operatorname{LW}(\mathrm{g})^{2}$ & $0.05 \pm 0.01$ & $0.04 \pm 0.01$ & $0.04 \pm 0.00$ & $0.05 \pm 0.01$ & 18.02 \\
\hline $\mathrm{FW}(\mathrm{g})^{*}$ & $0.02 \pm 0.0$ & $0.02 \pm 0.0$ & $0.02 \pm 0.0$ & $0.02 \pm 0.00$ & 15.15 \\
\hline Wvisc $(g)^{3}$ & $0.12 \pm 0.00$ & $0.11 \pm 0.01$ & $0.13 \pm 0.01$ & $0.15 \pm 0.02$ & 13.09 \\
\hline HSI $(\%)^{4}$ & $5.56 \pm 1.20$ & $5.65 \pm 1.13$ & $5.66 \pm 0.07$ & $5.90 \pm 1.42$ & 4.12 \\
\hline VFI $(\%)^{5}$ & $1.86 \pm 0.53$ & $2.69 \pm 0.43$ & $2.62 \pm 0.32$ & $1.76 \pm 0.16$ & 21.84 \\
\hline VSI (\%)* & $15.27 \pm 0.56$ & $13.36 \pm 1.24$ & $19.31 \pm 0.7$ & $14.82 \pm 2.02$ & 16.22 \\
\hline CY (\%)* & $83.24 \pm 0.49$ & $84.95 \pm 1.47$ & $78.45 \pm 0.7$ & $83.40 \pm 2.16$ & 3.41 \\
\hline CDM (\%) & $11.47 \pm 0.06$ & $10.21 \pm 1.33$ & $8.79 \pm 1.26$ & $10.20 \pm 1.22$ & 10.74 \\
\hline CEE $(\%)^{6}$ & $3.61 \pm 0.39$ & $4.7 \pm 0.58$ & $5.9 \pm 0.26$ & $2.4 \pm 0.09$ & 30.49 \\
\hline
\end{tabular}

${ }^{1}$ Coefficient of variation; ${ }^{2}$ Quadratic effect Pfig - Y $=1 \mathrm{E}-07 \times 2-7 \mathrm{E}-05 \mathrm{X}+0.048, \mathrm{R}^{2}=0.8735 ;{ }^{3}$ Quadratic effect PVisc-Y $=2 \mathrm{E}-07 \times 2-6 \mathrm{E}-05 \mathrm{X}+$ $0.1217, \mathrm{R}^{2}=0.8632 ;{ }^{4}$ Quadratic effect IHS-Y $=2 \mathrm{E}-06 \mathrm{x} 2-0.0004 \mathrm{x}+5.5031, \mathrm{R} 2=0.7827 ;{ }^{5}$ Quadratic effect IGV-Y $=-1 \mathrm{E}-05 \mathrm{x} 2+0.0057 \mathrm{x}+$ $1.9141, R^{2}=0.9498 ;{ }^{6}$ Quadratic effect EE-Y $=-3 E-05 \times 2+0.0159 x+3.4505, R^{2}=0.8177,{ }^{*}$ Not significant $(P>0.05)$.

The dispersion plots of the averages of the treatments and the polynomial regression equations for hepatosomatic index and visceral fat index, respectively, are presented in Table 2. The derivation of the polynomial equation showed that, from the $100 \mathrm{mg} \mathrm{VitC} \mathrm{kg}{ }^{-1}$ diet, the hepatosomatic index presented exponential growth. In contrast, the visceral fat index decreased from $285 \mathrm{mg} \mathrm{VitC} \mathrm{kg}{ }^{-1}$ diet.

The polynomial regression curve for ethereal extract (Table 2) presented exponential growth up to $285 \mathrm{mg}$ vitamin $\mathrm{C} \mathrm{kg}^{-1}$ diet, with a lower content of ethereal extract observed for the treatment with the $600 \mathrm{mg}$ vitamin $\mathrm{C} \mathrm{kg}^{-1}$ diet.

\section{Discussion}

According to Hoffmann et al. (1988), the thermal comfort zone of $L$. catesbeianus tadpoles are temperatures close to $25^{\circ} \mathrm{C}$, since it is at this temperature that they observed the best results of zootechnical performance.

Temperature is one of the most important environmental variables in aquaculture because it changes the balance between the synthesis and the degradation of biological structures and changes the metabolic requirements (Harpaz, 2005).

In the present study, the low temperature did not compromise the development and growth of the tadpoles, probably in response to the increasing levels of vitamin $\mathrm{C}$, which contributed to their satisfactory performance. Such observation can be corroborated with studies by Kitabchi (1967) and Dabrowski et al. (1994), who stated that ascorbic acid is a cofactor in the biosynthesis of steroid hormones. According to these studies, the increase in the availability of ascorbic acid can prevent the severity of the stress response in fish, reflecting on the improvement of the animal's development.

Falcon et al. (2008) observed that Nile tilapia exposed to a temperature of $15{ }^{\circ} \mathrm{C}$ showed an improvement in the immune system when supplemented with vitamin C.
Chen et al. (2002) observed that tilapias exposed to low temperatures presented high levels of serum cortisol.

The results of the present study indicated that supplementation of $600 \mathrm{mg}$ vitamin $\mathrm{C} \mathrm{kg}^{-1}$ of ration resulted in higher apparent feed intake and lower apparent feed conversion, reflecting higher weight gain and better protein efficiency. Probably the greater resistance to stress with higher levels of ascorbic acid has contributed to the improvement in performance.

The values of final weight and weight gain varied in a quadratic form up to $175 \mathrm{mg} \mathrm{VitC} \mathrm{kg}{ }^{-1}$ diet. However, the level that presented the best quadratic value for apparent feed conversion was $370 \mathrm{mg}$ vitamin $\mathrm{C} \mathrm{kg}^{-1}$ diet. Similar results were found by Navarro et al. (2010), who observed an improvement in the growth of Nile tilapia fingerlings supplemented with increasing levels of vitamin $C(0,50$, 100,150 , and $200 \mathrm{mg} \mathrm{kg}^{-1}$ ). Studying the effect of vitamin C supplementation on the diet of bullfrog tadpoles, Colombano et al. (2007) found that 2,000 mg vitamin C $\mathrm{kg}^{-1}$ improved weight gain and tadpole survival.

These results suggest that vitamin $\mathrm{C}$ acts in the formation of collagen, improving zootechnical performance. According to Rotta (2003), ascorbic acid directly influences fish growth because it plays an important role in the formation of collagen, which is the main component of the skeleton. According to Soliman et al. (1986), Nile tilapia supplemented with vitamin $\mathrm{C}$ displayed higher growth than animals fed without vitamin $\mathrm{C}$ supplementation. The authors concluded that ascorbic acid deficiency reduces thyroid uptake of iodine by increasing the plasma concentration of this mineral, suggesting thyroid hypoactivity. Thus, growth retardation can be attributed to the reduction in plasma levels of thyroid hormones that regulate growth.

Contrary to the results of the present study, De Stéfani et al. (2001) did not observe differences in tadpoles growth of 
tadpoles fed with ration supplemented with 50, 250, and $500 \mathrm{mg}$ vitamin $\mathrm{C} \mathrm{kg}^{-1}$. Knoop et al. (2015) also did not verify the influence of vitamin $C$ supplementation for postmetamorphosed bullfrogs. Probably the synthesis of ascorbic acid by frogs has been sufficient to meet their requirements.

It was observed that supplementation with $272.5 \mathrm{mg}$ vitamin $\mathrm{C} \mathrm{kg}^{-1}$ to the diet would be more adjusted to the requirements of the animals, providing greater efficiency in the use of the protein consumed for weight gain. According to Wilson, part of the ingested protein is used for energy production, so the values of protein efficiency may be a good indication that dietary protein was used for growth.

Lipids are the main source of energy reserve for animals and are usually stored in the liver, adipose tissue, or muscle, and are mobilized in response to the energy needs demanded by the process of growth, maintenance, and reproduction (Moreira et al., 2000). Thus, it is expected that the increase in the hepatic index reflects the assimilation of energy reserves by the animals (Agostinho et al., 1990).

Vitamin C is involved in energy metabolism because it participates in the synthesis of carnitine (Rotta, 2003), responsible for the transport of fatty acids from the cytoplasm to the mitochondrial matrix for $\beta$-oxidation of fatty acids. Thus, it can be inferred that high levels of vitamin C promote an increase in carnitine synthesis, reducing visceral fat deposition, and increasing liver activity. According to the study by Harpaz (2005), vitamin C deficiency may reduce carnitine levels. According to Lohninger et al. (1987), one of the first symptoms of vitamin $\mathrm{C}$ deficiency is related to the decrease in the carnitine synthesis, in which the animals present a state of fatigue.

In the present study, the analysis of the ether extract of housing and visceral fat index of tadpoles showed lower values at higher levels of vitamin C. This fact may be related to the increased use of lipids for energy production from the carnitine synthesis. According to Harpaz (2005), carnitine acts as a growth promoter by potentiating the use of dietary fats, conferring a protein-sparing effect.

\section{Reference}

Agostinho AA, Barbieri G, Verani JR, Hahn NS. Variação do fator de condição e do índice hepatossomático e suas relações com o ciclo reprodutivo em Rhinelepis aspera (Agassis, 1829) (Osteichthyes, Loricariidae) no Rio Paranapanema, Porecatu. Cienc Cult. 1990;42:711-4.
Fish subjected to low temperatures can increase the mitochondrial volume (Cordiner \& Egginton, 1997) and the activity of certain mitochondrial enzymes such as citrate synthase and carnitine palmitoyltransferase (St-Pierre et al., 1998). Guderley \& Johnston (1996) studied the impact of thermal acclimation in Myoxocephalus Scorpius submitted to experimental temperature $\left(2.5,7.5,12.5\right.$, and $\left.20^{\circ} \mathrm{C}\right)$ and observed that the activity of carnitine palmitoyltransferase enzyme increased by $42 \%$ in animals that underwent thermal stress. The authors observed that the increase of the enzymatic activity provided a better use of the fatty acids and glucose for energy production, therefore showing an adaptation to the low temperatures. Carnitine esters protect nerve cells from stress and deterioration, as they have antioxidant properties (Sinatra \& Sinatra, 1999). Products such as vitamin complex have high added values, so their use should be evaluated in terms of the cost-benefit in animal production.

\section{Conclusion}

The results obtained in this study suggest that vitamin C supplementation in the diet for bullfrog tadpoles improves the zootechnical performance and that $600 \mathrm{mg} \mathrm{VitC} \mathrm{kg-1}^{-1}$ is the optimal value.

\section{Conflict of Interest}

The authors declare no conflict of interests in the current manuscript.

\section{Ethics Statement}

The research was carried out according to Martins et al. (2016) number ethics committee for animal use 43079/2012.

\section{Acknowledgments}

We thank the research team of AcquaUnB of the University of Brasilia and all the students who contributed to the completion of the work. We also acknowledge the University of Brasília (UNB) and the Coordination for the Improvement of Higher Education Personnel (Capes), for financial support. Finally, we thank the Alipan company for supplying the feed.

Braga LGT, Lima SL. Influência da temperatura ambiente no desempenho da rã-touro, Rana catesbeiana (Shaw, 1802) na Fase de Recria. Rev Bras Zootec. 2001;30(6):1659-63. http://dx.doi.org/10.1590/S151635982001000700001 . 
Castillo ASC, Parra MAL. Respuestas fisiológicas de Piaractus brachypomus suplementado con ácido ascórbico y sometido a estrés por hipoxia. Rev Med Vet. 2019;38:2389-8526. https://doi.org/10.19052/mv.vol1.iss38.3.

Castro JC, Pinto AT. Qualidade de água em tanque de girinos de rã-touro, Rana catesbeiana, Shaw, 1802, cultivados em diferentes densidades de estocagem. Rev Bras Zootec. 2000;29(6):1903-11.

Chen WH, Sun LT, Tsai CL, Song YL, Chang CF. Coldstress induced th emodulation of catecholaminas, cortisol, immunoglobulin $\mathrm{M}$, and leukocyte phagocytosis in tilapia. General Endocrinology. 2002;126(1):90-100. http://dx.doi. org/10.1006/gcen.2001.7772. PMid:11944970.

Colombano NC, Fenerick J Jr, De Stéfani MV, Moraes FR, Souza MA, Malheiros EB. Suplementação alimentar com vitamina c e desempenho zootécnico de girinos de rã-touro (Rana catesbeiana). Acta Sci Anim Sci. 2007;29(3):333-8.

Cordiner S, Egginton S. Effects of seasonal temperature acclimatization on muscle metabolism in rainbow trout, Oncorhynchus mykiss. Fish Physiol Biochem. 1997;16(4):33343. http://dx.doi.org/10.1023/A:1007732003452.

Dabrowski K, Matusiewicz M, Blom JH. Hydrolysis, absorption and bioavailability of ascorbic acid esters in fish. Aquaculture. 1994;124(1-4):169-92. http://dx.doi. org/10.1016/0044-8486(94)90376-X.

De Stéfani MV, Marcantonio AS, Martins ML. Suplementação com vitaminas $\mathrm{Ce}$ E sobre o desenvolvimento e sobrevivência de girinos de rã-touro (Rana catesbeiana, Shaw, 1802). Cienc Rural. 2001;31(5):869-71. http://dx.doi.org/10.1590/ S0103-84782001000500021.

Drouin G, Godin J, Page B. The genetics of vitamin C loss in vertebrates. Curr Genomics. 2011;12(5):371-8. http:// dx.doi.org/10.2174/138920211796429736. PMid:22294879.

Falcon DR, Barros MM, Pezzato LE, Narvae WVS, Guimarães IG. Leucograma da tilápia-do-Nilo arraçoada com dietas suplementadas com níveis de vitamina c e lipídeo submetidas a estresse por baixa temperatura. Cienc Anim Bras. 2008;9(3):543-51.

Gao J, Koshio S, Ishikawa M, Yokoyama S, Mamauag REP. Interactive effects of vitamin $\mathrm{C}$ and $\mathrm{E}$ supplementation on growth performance, fatty acid composition and reduction of oxidative stress in juvenile Japanese flounder Paralichthys olivaceus fed dietary oxidized fish oil. Aquaculture. 2014;422:8490. http://dx.doi.org/10.1016/j.aquaculture.2013.11.031.

Godome T, Tovassi E, Ouattara NI, Fiogbe ED. Determination of the optimal feed ration for best growth of Hoplobatrachus occipitalis (Günther, 1858) tadpoles reared in controlled medium. International Journal of Fisheries and Aquatic Studies. 2018;6(2):376-80.

Gosner KL. A simplified table for staging anuran embryos and larvae with notes on identification. Herpetologica. 1960;16:183-90.

Guderley H, Johnston IA. Plasticity of fish muscle mitochondria with thermal acclimation. J Exp Biol. 1996;199(Pt 6):13117. PMid:9319187.

Harpaz S. 1-Carnitine and its attributed functions in fish culture and nutrition: a review. Aquaculture. 2005;249(14):3-21. http://dx.doi.org/10.1016/j.aquaculture.2005.04.007.

Hayashi C, Soares CM, Galdioli EM, Furuya VRB, Boscolo WR. Desenvolvimento de Girinos de Rã-Touro (Rana catesbeiana, Shaw, 1802) cultivados em diferentes densidades de estocagem em tanques-rede. Rev Bras Zootec. 2004;33(1):14-20. http://dx.doi.org/10.1590/S151635982004000100003 .

Hoffmann DF, Leboute EM, Souza SMG. Efeito da temperatura no ganho de peso de girinos de rã-touro, Rana catesbeiana Shaw, 1802. In: Anais do $6^{\circ}$ Simpósio Latinoamericano; Simpósio Brasileiro de Aqüicultura; 1988; Florianópolis, SC. Florianópolis; 1988. p. 799-803.

Kitabchi AE. Ascorbic acid in steroidogenesis. Nature. 1967;215(5108):1385-6. http://dx.doi.org/10.1038/2151385a0. PMid:6055456.

Knoop R, Dias DC, França FM, Antonucci AM, Teixeira PC, Viau P, Oliveira CA, Hipolito M, Ferreira CM. Vitamin C supplementation has on effect on American bullfrog's imune response. J Anim Physiol Anim Nutr (Berl). 2015;99(1):8591. http://dx.doi.org/10.1111/jpn.12207. PMid:24862607.

Leibovitz HE, Culley DD Jr, Geaghan JP. Effects of vitamin $\mathrm{C}$ and sodium benzoate on survival, growth and skeletal deformities of intensively cultured bullfrog larvae Rana catesbeiana reared at two pH levels. J World Maric Soc. 1982;13(1-4):322-8. http://dx.doi.org/10.1111/j.1749-7345.1982. tb00042.x. 
Lim C, Lovell RT. Pathology of the vitamin C deficeincy syndrome in channel catfish (Ictalurus punctatus). J Nutr. 1978;108(7):1137-46. http://dx.doi.org/10.1093/jn/108.7.1137. PMid:660305.

Lohninger A, Kaiser E, Legenstein E, Staniek H. Carnitine, metabolism and function. In: Kaiser E, Lohninger A. editors. Carnitine-Its Role in Lung and Heart Disorders. Basel: Karger Press; 1987. p. 1-25.

Martins TPA, Gomides PFV, Navarro FKSP, Navarro RD. Vitamin C supplementation on growth performance and gonadal development in Nile tilapia. Acta Sci Technol. 2016;38:477-81. http://dx.doi.org/10.4025/actascitechnol. v38i4.28788.

Moreira RG, Venturieri RLL, Bernardino G. Alterações sazonais hepáticas em Salminus maxilosus em ambiente natural. Boletim Técnico CEPTA, 2000;13:47-61.

Navarro RD, Matta SLP, Ribeiro Filho OP, Ferreira WM, Miranda DC, Pereira FKS. Morformetria e desenvolvimento gonadal em Tilápia do Nilo (Oreochromis niloticus) alimentadas com suplementação de vitaminas E. Arch Zootec. 2010;59:519-28. http://dx.doi.org/10.21071/ az.v59i228.4707.

Neu DH, Signor A, Feiden A, Diemer O, Finkler JK, Boscolo WR. Suplementação de Vitamina $C$ na dieta para larvas de mandi-pintado Pimelodus Britskii. Acta Vet Brasilica. 2010;4(4):242-6.
Pahor-Filho E, Mansano CFM, Pereira MM, De Stéfani MV. The most frequently bullfrog productive systems used in Brazilian aquaculture: A review. Aquacult Eng. 2019;87:102023. http://dx.doi.org/10.1016/j.aquaeng.2019.102023.

Rotta MA. Utilização do ácido ascórbico (vitamina C) pelos peixes. Corumbá: Embrapa Pantanal; 2003. 54 p.

SAS Institute. Statistical Analysis System: user guide [CDROM]. Version 8. Cary: SAS Insitute Inc.; 2008.

Sinatra ST, Sinatra J. L-Carnitine and the heart. New York: McGraw Hill; 1999. 64 p.

Soliman AK, Jauncey K, Roberts RJ. The effect of varying forms of dietary ascorbic acid on the nutrition of juvenile tilapias (Oreochromis niloticus). Aquaculture. 1986;52(1):110. http://dx.doi.org/10.1016/0044-8486(86)90101-8.

St-Pierre J, Charest PM, Guderley H. Relative contribution of quantitative and qualitative changes in mitochondria to metabolic compensation during seasonal acclimatization of rainbow trout Oncorhynchus mykiss. J Exp Biol. 1998;201:2961-70.

Zhou Q, Wang L, Wang H, Xie F, Wang T. Effect of dietary vitamin $\mathrm{C}$ on the growth performance and innate immunity of juvenile cobia (Rachycentron canadum). Fish Shellfish Immunol. 2012;32(6):969-75. http://dx.doi.org/10.1016/j. fsi.2012.01.024. PMid:22366311.

Financial Support: None. 